\title{
Vicarious vertigo: the emotional experience of height in the science fiction city
}

Article

Accepted Version

Creative Commons: Attribution-Noncommercial-No Derivative Works 4.0

Butt, A. (2018) Vicarious vertigo: the emotional experience of height in the science fiction city. Emotion, Space and Society, 28. pp. 114-121. ISSN 17554586 doi:

https://doi.org/10.1016/j.emospa.2017.04.001 Available at https://centaur.reading.ac.uk/79101/

It is advisable to refer to the publisher's version if you intend to cite from the work. See Guidance on citing.

To link to this article DOI: http://dx.doi.org/10.1016/j.emospa.2017.04.001

Publisher: Elsevier

All outputs in CentAUR are protected by Intellectual Property Rights law, including copyright law. Copyright and IPR is retained by the creators or other copyright holders. Terms and conditions for use of this material are defined in the End User Agreement.

$\underline{\text { www.reading.ac.uk/centaur }}$ 
Central Archive at the University of Reading

Reading's research outputs online 
Vicarious vertigo: The emotional experience of height in the science fiction city

\begin{abstract}
:
In the light of the rapid proliferation of high-rise urbanism, can the science-fiction (sf) cities of an imagined future provide an insight into the emotional impact of those currently under construction? This paper builds on the call from within urban studies for greater scholarship into vertical urbanism through the common ground of $s f$, to reflect on the emotional affect of building high.

The emotional implications of living at height are most strongly felt through the experience of vertigo, a fundamental human response to our embodied sense of self within our environment overlaid with potent emotional connotations. This paper focuses on two sf texts; Robert Silverberg's The World Inside (1971) and JG Ballard's High Rise (1976), where the reader is prompted to both empathetically engage and imaginatively enact the experience of vertigo. The critical estrangement of these novels allows the emotional impact of vertigo on the imagined inhabitants to be critically appreciated alongside the personal experiences of the reader. They provide a space to reflect on the cities we already inhabit, and reveal the importance of attending to the emotional affect of built environment to establish a sense of place in this new vertical world.
\end{abstract}

\title{
Keywords:
}

Vertigo; Science-Fiction; Verticality; Cities; Urban; Fiction 


\section{Introduction}

In March 2016 High Rise, the film adaptation of JG Ballard's 1976 novel set in a 40 storey tower in London's Docklands, had its premiere screening in London. In the same month that this retro-futuristic vision of high-rise urbanism was aired, New London Architecture updated its comprehensive review of the current status of high-rise development (New London Architecture, 2016). It details the 436 tall buildings currently in the pipeline in London; a dramatic enough figure in isolation, it also revealed that 119 of these were new developments submitted for planning permission in the preceding 12 months. Alongside the welldocumented iconic heights of buildings such as the Burj Kalifa, which at 163 storeys high dwarfs the vision of Ballard, this abundance of high-rise development in cities such as London demonstrates the extent to which vertical urbanism and the experience of living at height are rapidly becoming ubiquitous and inescapable parts of everyday urban reality.

This surge in construction of new high-rise developments has led to a vital body of criticism. Studies such as those undertaken by urban geographers Lees et al. (2009) and Watt (2009) delineate the dizzying spatial inequality inherent in the construction of towers that maximise inner city land value, alongside the privatisation and demolition of existing social housing. These texts draw much needed attention to these developments, creating a body of resistance against this insidious spatial segregation. However, in focusing on the economic or social implications of these processes, the emotional affect of these spaces is often overlooked.

Within the fields of planning, geography and urban studies, Brown and Pickeril (2009, p. 33) state it is necessary to "overcome the fear among some activists that to engage in emotional reflexivity is narcissistic and time-wasting, instead making explicit the link between understanding our emotions and prefiguring social transformation." Ansaloni and Tedeschi (2016, p. 15) note that this requires an appreciation of "affect and emotion as politically crucial subjects for understanding socio-spatial processes in urban contexts".

This paper builds on debates around the role of emotion and affect in the co-production of space, which underpin its critique in the design of urban environments (for example: Anderson, 2009; Johnson, 2011; and McGaw and Vance, 2008). I argue that there is scope for greater consideration of the role of emotion in the co-production of urban space within the fields of urban design, planning and architecture. There is critical work being done in this field, such as the projects of Snaberg and Rönnblom (2016), who gather and examine emotional narratives around urban transformation. However, Baum (2015) decries the fact that this aspect of design remains overlooked by practitioners who focus on the "rationality" of planning.

While Thrift's statement that "generally speaking, to read about affect in cities it is necessary to resort to the pages of novels," (2004, p. 57) may no longer be true, this paper argues that science fiction (sf) novels can continue to form a critical part of discussions into the emotional impact of the future city. Novels such as High Rise, written during a period of similarly untrammeled vertical construction, explicitly address the emotional experience of living at height. As many cities grow upwards into the heights that were previously the realm of sf, these novels provide their readers with ways to both imagine and empathetically experience the emotional impact of the built environment. Critically, these novels also provide architects, designers and planners with a space to reflect on the emotional implications of the cities currently under construction.

\section{The experience of vertigo}

Throughout this paper I use the term 'vertigo' to refer to the symptoms of 'height-vertigo' or 'distance-vertigo' (Guerraz et al., 2001). It is a term commonly conflated with acrophobia or fear of heights, the psychological desire to avoid environments where the sensations of 
vertigo might be provoked. LeBlanc (2011) describes how, through reading Sartre, vertigo can be understood as the as a fear of an external threat that becomes internalised as existential anxiety. For those who are susceptible, vertigo can be both physically and emotionally destabilising, as LeBlanc summarises, "vertigo prompts serious questions about the nature and stability of one's self" (2011, p. 2). While these severe responses are rare, the sensations of vertigo itself are an innate biological response to distance or height (Walk et al., 1957 cited in Brandt, 2003, p. 422). As such, the experience of vertigo can be considered as a common embodied response to the built environment.

The sensation of vertigo is characterised in neuroscientific study by feelings of dizziness, loss of balance, disorientation and sensations of movement or rotation (see Brandt et al., 1980; Whitney et al., 2005). These sensations are created by an inter-sensory conflict, as visual information regarding relative stability is at odds with the other sensory inputs. When, as described by Brandt, "the distance between the observer's eye and the nearest visible stationary contrast becomes critically large" (Brandt, 2003, p. 418). In this way, it is distance rather than direction which provokes height-vertigo, and in the context of the built environment it can be created by either a downwards glance to the streets below, or upwards gaze towards the looming heights of the tower.

Critical to the understanding of the use of vertigo in fictional representations of the city is the appreciation that, as a physiological reaction, it can be considered a universal experience. It is a fundamental human response to our embodied sense of self within our environment, which is overlaid with potent emotional or existential connotations. Within the vertical cities of sf, the experience of vertigo offers an opportunity to consider the role an embodied sense of location plays in our emotional appreciation of place.

\section{The city and the imagination: a conceptual role for sf}

This paper follows urban geographers Hewitt and Graham's (2015, p. 925) call for greater study of the "vertical and volumetric nature of the urban environment and experience that is at the core of contemporary urbanism". They identify an embedded horizontalism in urban research which is unable to respond to the radical reshaping of the vertical and volumetric built environment (see also: Elden, 2013; Harris, 2015; Hewitt and Graham, 2013; McNeill, 2005). As described by Graham (2016a, p. 41) the "flattening effects of both geographic and urbanistic traditions work to seriously undermine the emergence of a fully three-dimensional understanding of these crucial transformations". The existence of what Harris $(2015$, p. 601) has referred to as "a vertical blind-spot" across contemporary urban theory restricts our conceptualisation of the city and fails to reflect the multi-layer urban reality which we are beginning to inhabit.

Ireson (2000) argues that a shift in perspective is required to examine and critique vertical urbanism to develop an appreciation of different levels as distinct contexts, each creating specific patterns of architectural design, or types of interaction. The need for this conceptual shift is reflected in the lived experience of multi-layer vertical urbanism in Hong Kong, where stacked and overlapping malls, skyways and towers create a multiplicity of planes on and between which city life occurs. Here, ground level is no longer the predominant site of public lived experience, leading to a description of Hong Kong as a 'city without ground' (Frampton et al., 2012; Shelton et al., 2014; Steyerl, 2011). This 'loss of ground' is a fundamentally destabilising act, literally undermining traditional modes of mapping and navigating the city.

In response to the rapid pace of change within urban development, and the embedded horizontality of traditional modes of urban studies theory and critique, Hewitt and Graham (2015) have argued that sf provides a site for the potential reconceptualisation of the city. Within geography, planning and urban studies, extrapolative sf is predominantly considered as either a prediction of the future of cities, or as a vehicle for critique of contemporary cities. 
I argue for an extension to this reading, drawing on work that examines the ways fiction and contemporary theory can be co-considered, to critique current theoretical understandings of the city (Abbott, 2007; Collie, 2011; Davis, 1992; Gold, 2001; Hewitt and Graham 2015; Kitchin and Kneale, 2002; Lewis et al., 2008). Kitchin and Kneale (2002, p. 9) extol the value of the "privileged site" of sf in particular as creating a tension between reality and fantasy, between science and fiction, "from which to contemplate material and incursive geographies and the production of geographical knowledges and imaginations."

Sf theorist Suvin (1979) considers this potential to create a new site from which to contemplate the real alongside the imaginary as the defining characteristic of sf. Through his conception of 'cognitive estrangement' he identifies a process of critical detachment for the sf reader. For political theorist Jameson $(2005$, p. 99) this estrangement through idea acts both on the fiction being presented and the reality from which the reader views it, and he describes sf as presenting "messages of otherness, but transmitted in the past". The cognitive estrangement of sf comes from its ability to make the reader 'other', to view both the real and imagined alongside one another, and provide a detached and elevated perspective on the trends and concerns of the everyday present.

For Jameson, imaginative freedom is the critical factor which differentiates sf from other forms of literary expression. This is in part rooted in the genre's 'pulp' character, its selfdefinition as existing outside of high art (Bloom, 1996; Fisher, 2014). As Jameson states it is only in sf that there is the "capacity to relax that tyrannical 'reality principle' which functions as a crippling censorship over high art" (2005, p. 270).

Following Suvin and Jameson, I argue that the value of sf in relation to the built environment is twofold. Firstly, the radical imagination of an environment which is entirely 'other' allows the reader to imaginatively inhabit and experience place. Secondly, through this othering, the reader gains critical distance from the built environment as it is currently known, to examine their own emotional experience of space.

\section{$\underline{4 .}$ The vertical city in sf cinema}

While the vertical has been overlooked in urban theory, Graham (2016b, p. 382) describes how "the image of the radically verticalised cityscape has so dominated science fiction as to be almost a cliché." This is certainly the case across science fiction film, where, as argued by Barlow (2005, p. 43) "the 'standard' version of the city of the future now comes from the Los Angeles that Scott and his 'visual futurist' Syd Mead created for Blade Runner."

While the vertical city may be considered as a 'standard', its metaphorical role is far from constant. In her analysis of the city throughout the history of sf film, media theorist Sobchack (1988) details how these representations offer a situated glimpse into the symbolic role of the vertical city. How it has been transformed; from a utopian space in films such as Things to Come (1936); Lost Horizon (1937) and The Wizard of Oz (1939) to a "symbol of modern civilizations aspiration and pride" (1988, p. 10). As noted by Sontag (1964), these buildings became the focal point of sf cinemas dominant "aesthetic of destruction," used to denote civilization in ruins. Sobchack (2014) goes on to chart how this association of verticality has become synonymous with; an asphyxiating oppressiveness in films such as Soylent Green (1973) and Logan's Run (1976), through the "dense, complex and heterogeneous" spaces of Blade Runner (1982) and Brazil (1985), and the bottomless and unfathomable spaces of Fifth Element (1997) and Dark City (1998).

\section{The active reader}

These films convey the affective impact of the city through both the scenography, and through empathetic sharing of the protagonist's responses. Keen (2007), in her examination of 
the role of empathy in fiction, outlines this spontaneous sharing of affect is biologically engrained, what neuroscientists including Gallese (2003) call a 'shared manifold for intersubjectivity'. As we witness the protagonists experience physiological sensations of vertigo, we empathetically experience the emotions which accompany these sensations; feelings of uneasiness, helplessness and panic which can develop into existentially challenging feelings of loss and fear.

One distinction between the comparative impact of reading about an experience versus witnessing that experience on film is espoused by 'enactivist' literary theory. This is framed by the conception of emotion as inherently embodied (McGann and Torrance, 2005), and reflects the work being done in the field of geographies of emotion (Davidson et al., 2005). In this conception, written descriptions of an experience cause them to be imaginatively enacted by the reader (Keen, 2007). In this way, reading about the imaginary city not only causes the reader to empathetically relate to a character's emotional reaction, but also to undergo an embodied imaginative recreation of that experience, intertwining their emotional reactions to both real and imagined.

As well as being subject to a heightened engagement with the environment, the reader of a fictional text can also be considered actively involved in its creation. Following the work of literary theorist Iser (1978), descriptions of a fictional world cannot be exhaustive. As such there are 'gaps' which require the reader to actively infer from or interpolate into the text. Within sf, the 'gaps' can be considerably greater than those in literary fiction, requiring what Spencer (1983) has termed "reciprocal reading protocols". Here, the reader fills in gaps with their own experience to create a cohesive whole, while simultaneously observing the implications of that world on the narrative. As Spencer describes, "the reader oscillates between involvement in, and of observation of, the world of the text" (1983, p. 36). I argue that this process of construction and reflection is a critical part of the 'cognitive estrangement' of sf. Subsequently, the reader is offered a critical perspective on not only the world of the text, but also their own subjective experiences that are woven into it. When considering the affective emotional experience of the city, this engagement with its imaginary construction draws readers to both empathetically engage with the experience of the protagonist, and also to reconstruct, re-live and reconsider their own emotional experience of place.

\section{$\underline{\text { 6. Verticality in sf literature }}$}

There are notable examples of the vertical city throughout sf literature; from HG Wells' seminal novel When The Sleeper Wakes (1899) and the oppressive towers of glass in Zamyatin's $W e$ (1921), through to the more contemporary visions such as the isolated highrise refuges in Maggie Gee's The Flood (2004), and Paulo Bacigalupi's The Windup Girl (2009). However, there was a particular proliferation of texts in the period from the mid1960 s to late 1970 s which specifically address the emotional implications of the vertical city.

These texts were part of the New Wave (NW) movement within sf, which developed in the 1960s in response to wider counter-cultural movements in the UK and US (Broderick, 2003). These authors saw the role of sf as the exploration of what J.G Ballard termed "'inner space', rather than 'outer space"' (1962, p. 118). Greenland notes that they avoided the prevalent tropes of alien invasion or deep space exploration, to focus on "the external worlds as transformed and encoded by the individual consciousness" (2013, p. 51).

This concern for social structures and inner lives is reflected in texts which explore the impact the built environment has on its inhabitants, and its imagined development. Greenland describes how they "used their novels to criticise not only the society within which they wrote, but also the possible utopian alternatives" (2013, p. 51). In this way the prevalence of high-rise futures within sf in the period from the mid-1960s to late 1970s can be understood 
as both an extrapolation of the world in which they wrote and as a setting which allowed them to critique alternatives.

The vertical city is prevalent as a trope in NW sf of this period, and a by no means comprehensive list of novels which feature a tower city might include; Beyond the Sealed World [1965], Make Room! Make Room! [1966], A Torrent of Faces [1967], Stand on Zanzibar [1968], Tower of Glass [1968], The City Dwellers [1970], The World Inside [1971], 334 [1972], The Castle Keeps [1972], Growing up in Tier 3000 [1975], High Rise [1975], Cinnabar [1976], and Catacomb Years [1979].

There is much potential for further scholarship to be done on these novels as a group, however, High Rise and The World Inside provide the most rigidly delineated examples of vertical cities. The buildings they depict are almost entirely self-contained, and as a consequence the inhabitants are offered no respite from the psychological pressures they exert and their lives are intrinsically intertwined with the experience of the vertical city.

These novels have been examined in terms of their representation of social hierarchy (Abrash, 2002; and Hicks, 2014), but these readings tend to overlook their evocative representations of the individual emotional experience of place. A notable exception is the work of planners Ansaloni and Tedeschi (2016) who use the novel High Rise as a site for considering the emotional affect and social implications of 'poor doors' in London. This study unpicks the escalation from humiliation and uneasiness to fear and rage in both reality and fiction, using the language of the novel to convey emotional reactions. This provides a useful tool to engage in discussions of emotional affect, through an expressive common narrative which "closely tracks" the reality of socio-spatial division (2016, p. 15). However, this reading of High Rise risks flattening the critical potential of these novel by considering them only as expressive extrapolation. Rather, the estrangement of sf also provides a necessary moment of critical reflection on the cities we are creating and our emotional reactions to them.

\section{The myth of the high-rise}

While the NW broadened the number of contributing writers and reader of sf (Le Guin, 1997) it remained focused on the existing sf communities in the UK and the US. Within the UK, the NW movement was loosely centered in London (Roberts, 2005). JG Ballard who was central to this movement, was living in a suburb of London when he wrote High Rise. NW editor Merrill (1967) notes that the movement was "less cohesive" in the US, without the defined center of a particular place or publication. But at the time of writing The World Inside, Robert Silverberg had recently moved from his native New York to San Francisco.

While it would be an oversimplification to say that the setting of these novels is a direct extrapolation of high-rises in London and New York, they can be read as a response to the dominant narratives which surrounded these buildings in the UK and US. The historical complexity of the development of modernist high-rises is beyond the scope of this paper. However, studies such as Glendinning and Muthesius's comprehensive text Tower Block (1994), demonstrate that these developments were primarily driven by a shared belief which can be considered as a utopian programme. This reconstruction of the physical fabric of the city can be understood as a critical part of the wider 'modernisation' of socio-political values (Pinder, 2005; White, 2009).

In this way, the extensive construction of high-rise housing in the 1960s, rising from 6,000 blocks of 6 or more storeys in the UK in 1956 to 44,000 blocks in 1966 (Dunleavy, 1981), was linked in popular imagination to an implicitly utopian programme for social progress. As environmental planners Chen and Shih describe, the high rise emerged "as a powerful site and symbol for collective aspirations and imaginations" (2009, p. 330). 
However, for Glendinning and Muthesius "what makes the story of the 'reception' of Modern housing so immensely complicated and controversial is not so much the complex debates of the time, but the criticism which developed afterwards" (1994, p. 5). This public criticism centered on a still prevalent narrative arc of dystopian 'failure' that equates the high-rise building form with notions of social unsuitability, and largely ignores wider social, political or economic contextual considerations.

In both the UK and the US the destruction of single iconic blocks were held as evidence of the 'failure' of this programme. In the UK, social historian White speculates that the "death knell rang loud and sudden for the tower block on 16 May 1968" (2009, p. 56) following the tragically fatal collapse of the Ronan Point tower block in East London. The demolition of the Pruitt-Igoe housing development was a similarly symbolic moment in the US, which led architectural historian Jencks to declare that "modern architecture died in St. Louis, Missouri on July 15, 1972 at 3.32pm" (1977, p. 9).

Despite the contextual complexities of individual high-rise buildings which preclude generalisation, extensive academic study has been undertaken into whether these buildings can be deemed to have 'failed' in any objective sense (Gifford, 2007; Hillier, 1973; Spicker, 1987). Critical to this inquiry is an appreciation that the perception of the built environment is fundamentally shaped by cultural context (Ingold 2000). This is supported in empirical studies of high-rise homes in cities such as Hong Kong or Singapore (Jacobs and Cairns, 2008; Yuen et al., 2006), whose work suggests that the affective implications of living at height are far more culturally situated and socially complex than the predominantly western cultural narrative of 'failure' intimates. However, when considering the role of these buildings in sf, the validity of this narrative of failure becomes less critical than its subsequent interpretation. As elucidated by Forty, with regard to the perception of British modernism, "we need not concern ourselves now with whether or not it actually was a failure ... what matters is that it has been perceived to have been a failure" (Forty, 1995, p. 25).

These novels draw upon this conflict within the history of the high-rise; existing as both a symbol of utopian promise, and a demonstration of the failure of a utopian programme. An emotionally evocative space, it promises the joy of enlightened existence, but becomes associated with depression and isolation, pushing its inhabitants towards frustration and rage.

\section{$\underline{8.1 \text { High Rise }}$}

The tower block JG Ballard's High Rise most closely resembles the present-day incarnation of the high-rise, a 40 storey tower block in an alternative present of suburban London. Ballard's inspiration is reported to have been existing modernist blocks, (see Frith, 2009; Gąsiorek, 2005) including Le Corbusier's Unité d'Habitation and Ernö Goldfinger's Trellick or Balfron Tower.

With its forty floors and thousand apartments, its supermarket and swimming pools, bank and junior school - all in effect abandoned in the sky - the high rise offered more than enough opportunities for violence and confrontation. (2006, p. 7)

Ballard radically departs from the reality of lived experience in these blocks to present a violently exaggerated response to the high-rise. In High Rise, the building encourages the residents to isolate themselves within the tower, enabling their descent into savagery. Its unyielding concrete materiality lends it a brutal and dehumanising aspect, and this brutality becomes embedded in the collective psyche of its residents. This is exacerbated by its implicit hierarchical organisation which encourages tribalism, and the buildings spatial detachment from its surroundings which symbolically removes them from the social rules which govern 
the world outside. As a result, the apparently heinous acts committed within the high-rise are undertaken without any accompanying emotional turmoil, rather they are accepted with serenity as a new form of truth.

Throughout the novel Ballard repeatedly refers to the building as a "cliff face" into which the residents have "slotted themselves". This vertiginous metaphor suggests that, while to the outsider the block presents an unyielding and dominant façade the residents within feel a growing complacency towards their vertical location. Bould has interpreted these references as an allusion to the first high-rise novel, Henry Blake Fuller's The Cliff-Dwellers (2016). The cliff implies a natural phenomenon, and it casts the block as a series of stacked caves into which a more primal version of humanity can retreat.

This shift in the emotional state of the inhabitants can be traced in two scenes which make the scale and physical detachment of the high-rise apparent through the experience of vertigo. These are experienced from the perspective of Dr Robert Laing, the "truest" inhabitant of the high-rise and one of the first inhabitants to emotionally reconfigure himself to suit high-rise life. The first scene, occurs towards the beginning of the novel;
A bottle of sparkling wine had fallen from a floor fifty feet above, ricocheted off an awning as it hurtled downwards, and burst across the tiled balcony floor .... He leaned out over the rail and peered up at the face of the building, carefully counting the balconies. As usual, though, the dimensions of the forty-storey block made his head reel. Lowering his eyes to the tiled floor, he steadied himself against the door pillar. The immense volume of open space that separated the building from the neighbouring high-rise a quarter of a mile away unsettled his sense of balance. At times he felt that he was living in the gondola of a ferris wheel permanently suspended three hundred feet above the ground. $(2006$, p. 8 )

The second scene is an echo of the first, occurring a few nights later in the timeline of the novel.
They had reached the french windows when there was an explosion of breaking glass from a balcony high above them. Fragments of glass flicked away like knives through the night air. A large, ungainly object whirled past, no more than twenty feet from the balcony.... All around, people were leaning on their railings, glasses in hand, staring down through the darkness. Far below, embedded in the crushed roof of a car in the front rank, was the body of a man in evening dress. ... Laing held tightly to the metal bar, shocked and excited at the same time. Almost every balcony on the huge face of the high-rise was now occupied, the residents gazing down as if from their boxes in an enormous outdoor opera house. (2006, p. 41)

The first experience of vertigo is expressed as sensation of spinning and movement, enacted in the mind of the reader as we imaginatively follow the falling trajectory of the bottle down the building façade. We empathetically engage with Laing's experience of vertigo, physically manifest in his need to grasp the building to reassure himself of its solidity and to hold himself from falling. This is accompanied by feelings of disorientation and loss of control, an unsettling of self and a slight thrill in surrendering to helpless reliance on the building.

As these descriptions cause the reader to empathise or enact the sensations felt by Laing, the description of the physical form of the high rise becomes irrevocably intertwined with its emotional affect. The 'immense volume' of open space between the buildings and the 'dimensions of the forty-storey block' become aspects which are too vast for Laing to intellectually comprehend. His physical response, to seek reassurance in the solidity of the block and certainty in his own position, reflect his feelings of fear and establish the building as the source of both disorientation and reassurance. 
In the second scene, Laing witnesses a fall from the tower which results in the death of a resident. While the trajectory of the fall is again described, it is met with none of the unsettling sensations of dizziness or disorientation which accompanied the earlier descent of the wine bottle. Laing and the other residents are now able to lean out over the balcony edges, steadied only by the railings. Laing has become emotionally numbed to the surroundings, anesthetized by exposure and alcohol.

This detachment and withdrawal from the emotional impact of the environment is echoed in Laing's reaction to this tragic death. Rather than being horrified or disgusted, Laing is shocked but exhilarated. Around him residents look down into the darkness, observing the mangled body with the same sense of contented detachment as they would observe a scene played out on stage, as if the height has rendered the world below unreal.

For the reader, this lack of emotional reaction is disturbing. For the reader, the descriptions of the death prompt the same unsettling and disorienting emotions which accompanied the sensations of vertigo in the first scene, coupled with horror and disgust at the 'mangled body'. But our empathetic mirroring of Laing's emotional state conflicts with these feelings, and his exhilaration is all the more discordant by comparison. The vertigo which had troubled Laing previously has been lost, and this loss appears symptomatic of a loss of perspective; as the residents have become numbed to their location they appear to have relinquished a critical part of their emotional selves.

A new social type was being created by the apartment building, a cool, unemotional personality impervious to the psychological pressures of high-rise life. (2006, p. 35)

The initial descriptions of the high-rise encourage the reader to link this fictional space with real spaces which have elicited similar experiences of vertigo. This accord is then disrupted as the building transforms the anticipated reactions of the residents. In creating this discord between the emotional state of the reader and the character, Ballard foregrounds a tension between the subjective reality of the reader's own experience of the city and the fiction of the novel. Following Kitchin and Kneale (2002), this tension provides a critical site for the reader to examine their own reactions to the descriptions of height and scale, to question why the contentment of the residents is so jarring. In doing so the reader is able to view their own reactions from an estranged position, from the viewpoint of the 'other' to both reality and the perspective of the High-Rise residents. When viewed from this critical distance we are forced to confront the memory of spaces which filled the 'gaps' to enact the experience of vertigo, and view these spaces critically.

By creating this slippage between apparently banal reality and the violent space of the novel, Ballard forces us to confront the potential for terror within our cities. The novel implies there is a delicate threshold in terms of scale and height which designers and architects must consider carefully. Exceeding these limits holds the potential to inspire terror in the short term, but it may also force us to adapt, to detach ourselves emotionally from the impact of these spaces. In this way, High-Rise prompts us to question to what extent an emotional reaction to height or scale, either as awe or terror, is an intrinsically human response. It asks if the mass proliferation of spaces which gradually push us beyond these limits might numb us to a critical aspect of our emotional sense of place.

\subsection{The World Inside}

Rather than an alternate present, Robert Silverberg's The World Inside explores the spatial implications of a dramatic future increase in global population. To sustain these growing cities the pressure on arable land has increased, and this has forced the cities to coalesce, pushed upwards by the demands of intensive agriculture. The physical constraints of the 


\section{Vicarious vertigo: The emotional experience of height in the science fiction city}

tower have redirected the development of humanity and society is consequently defined by this urban form.

The towers of the Chippits constellation, fifty mighty concrete piles, each a self contained entity housing some 800,000 human beings. (2011, p. 26)

Access to the outside is forbidden and the primary purpose of govermnment has become the delicate management of humanity within this confined space. Those who are unable to adapt are branded 'flippos' and thrown down the chute to be burnt for fuel.

How could trouble makers be allowed to remain in the tight, intimate, carefully balanced structure of an urbmon? He knows that the probable result of tossing flippos down the chute has been, over a couple of centuries, the creation of a new style of human being through selective breeding. Is there now a homo urbmonensis, placid, adjusted, fully content? (2011, p. 76)

One of the repercussions of this rigid enforcement is that the experience of vertigo has been almost eliminated, either bred out or supressed as an incapacitating weakness in residents who live hundreds of floors above ground level. The disruptive potential of an emotional response to the overwhelming scale and suffocating enclosure of this future city is exemplified in the experiences of two residents. For both an experience of vertigo is synonymous with a breakdown in their conditioning.

Aurea, an inhabitant of the 735th floor, is able to look down from the tower during the day with a numbed neutrality. She observes the ground below without any physiological response, feeling a proud and placid ease in her environment.

Aurea halts by the majestic window at the dormitory's western end and stares out. The sunset is beginning. Across the way the magnificent bulk of urban monad 117 seems stained with golden red. Aurea follows the shaft of the great tower with her eyes, down from the landing stage at its thousandth floor tip, down to the buildings broad face. She cannot see at this angle very far below the $400^{\text {th }}$ floor of the adjoining structure. (2011, p. 25)

While Aurea has managed to supress her reaction to height during the day she finds that in her dreams she is always falling, plunging and spinning down from the heights of the tower.

In her dizziness she seems to vault to the edge of space ... she tumbles through the cold air, and she sees the spiky tips of the Chippitts tower below her, and she drops towards it ... And she wakes, sweating and shaking, her tongue dry, her mind dazed by a vision beyond her grasp. (2011, p. 34)

In the initial quote, Aurea's peaceful and sedate state in response to this "magnificent bulk" is startling, and it shocks us into an awareness of the social and emotional difference between our own perception of space and that being portrayed. As in High-Rise, the reader is prompted to anticipate sensations of vertigo by the downwards glance, and when this reaction is not forthcoming it makes the reader's own empathetic response jarring. While in High-Rise the reader is made continually aware of this emotional disconnect between reality and text, in The World Inside the reader is drawn into this city and prompted to empathise with the contentment and joy which Aurea apparently finds in her environment.

Having thus established an emotional baseline of placid contentment, a further process of estrangement is created through Aurea's own shift in perspective during her nightmares. Her 
dreams of falling prompt a mortal terror, and these scenes seem to exaggerate and extrapolate the vertiginous sensations felt by the reader when the tower is first introduced.

Within the novel, these vertiginous visions define Aurea as an outsider within her society, and are treated as a symptom of mental illness. In this way the experience of vertigo is used to demonstrate the inflexibility of the tower, unable to accommodate human frailty. It makes vertigo synonymous with weakness, an inherited trait which can be selected and suppressed, undesirable in this new type of human created to suit this inhuman environment.

Similarly well suited to this new future, Sigmund is an ambitious civil servant who strives to attain a position of influence within the governing elite of the tower. His political ascent is mirrored in his physical relocation upwards, as in High Rise, social stratification has been literally translated into the floorplates.

His ascent requires him to climb the tower via the single spiral staircase which winds its way up the building, all 1000 floors connected via a single void. As inhabitants are unable to leave, this is the only place within the tower where its height can truly be appreciated. In this space he is finally confronted with the true scale of his environment.

Plodding up the great coil that runs the whole thousand floor height of urban monad 116. He looks up the mighty helix and sees the levels stretching toward infinity ... He grasps the rail and looks down, eyes spiralling along the descending path. .... A dizzying vortex, a monstrous well through which the light of a million globes drifts. (2011, p.172)

The visual spiralling effect overwhelms Sigmund, and he experiences a dizzying and disorientating sensation of vertigo induced by height and depth. He grasps on to the railing in an attempt to steady himself, a fragment of reassurance in the face of the "monstrous" void. The existential fear and disorientation he experiences is described as "a sense of coming apart. A dislocation of the soul" (2011, p. 175).

The sparse descriptions of the 'coil' and 'spiral path' requires that the reader fill in the gaps with similar spaces from their own experience. As with the previous examples, these remembered experiences are then overlaid with the visual tracing of movement, of falling or "spiralling" downwards in a way that prompts an enactment of any personal experience of vertigo.

For Sigmund, his feelings of panic and despair are perceived as a sign of mental instability. His inability to cope at the higher levels means he is physiologically unsuitable for the social and physical position he has striven to attain, and the accompanying sense of loss and rejection overwhelms him.

Within The World Inside, society is rigidly defined by the experience of the city and the individual defined by their vertical location. In this setting, Sigmund's experience becomes a spatialised narration of anguished instability. As described by Davidson (2003, p. 3), vertigo can be "experienced as an unbearable attack on one's sense of self in space, constituting an unmitigated existential threat," which centers on the loss of self. Sigmund is confronted by a glimpse of a city whose scale overwhelms even the most well adapted, and he shatteringly fails to retain his previous equilibrium and peace. Unable to reassure himself or regain his previous contentment he is driven to feel he has no place in this society, and he is consequently overcome with depression and despair, and is eventually driven to suicide.

In creating this profound loss of place, Silverberg establishes a tension between the reader's initial response to this overwhelming and oppressive world, and the desire of its inhabitants to call it home. The estrangement created between the way we imagine we would feel within 
these spaces, and the way these inhabitants respond provides us with critical space to examine the social, cultural and psychological bias we hold towards certain configurations of space. While Ballard prompted us to question the intrinsic links between emotional and environmental limits, Silverberg questions just how malleable those limits are by pushing the notions of environmental adaptation to an extreme.

In this novel the feelings of loss are intrinsically linked to the sense of being lost, that without a sense of place it is impossible to feel contentment. The initial feelings of ease expressed by Aurea and Sigmund prompt the reader to reflect on similarly comforting spaces, and the shattering grief which accompanies the loss of 'home'. From this critical perspective, the scale of the fictional city becomes less critical than the inhabitant's ability to navigate it. For architects and designers, the critical challenge posed by this novel is how to establish a sense of place in cities or towers whose scale can be considered 'ground-less' and mystifying.

\section{Conclusion}

As demonstrated in this paper, the radical imagination and cognitive estrangement of the sf novel provides a way to critically reimagine the impact of the vertical cities currently under construction. While there is scope for greater scholarship into both vertical urbanism and into the critical space offered by sf for the consideration of urban development, I would extend this call to encompass the reading of sf novels more generally. As argued here, scholarship into the use of estranged critical perspectives offers opportunities to reflect on the emotional affect of place. These novels provide a shared language and narrative which can be used as a tool to describe the emotional impact of urban change, offering a common point of departure for design discussions. More critically, I argue for study into the potential for reading sf as a critical or pedagogical tool for urban designers and architects. As a space which is radically 'other' they hold the potential to encourage creativity and alternative conceptions of development within spaces whose narratives are driven by an awareness of the emotional affect of place. While their creation of 'cognitive estrangement' provides a space for designers to critically examine their own emotional responses to urban space, and consider the critical importance of emotional affect in design development.

The analysis of the experience of vertigo within these novels offers two critical points of reflection for those engaged in the design and development of the future city. The first is the physiological impact of experiences of vertigo, a problem that can be considered to be intrinsic to the creation of vertical urbanism. When designing ever-taller towers and cities it is necessary to ensure that we do not create spaces which exacerbate this deeply unsettling condition. The second, and more often overlooked, is the emotional affect of the multi-layer city which is synonymous with the experience of vertigo in these novels. Here the sensations of disorientation are presented as an embodied reaction to overwhelming scale, acting both as a metaphor for the overwhelming confusion of the city and as a prompt for the reader to imaginatively enact the experience of being lost.

It is this subtle but critical need to locate ourselves within the city which these novels bring into focus, and in comparison to the physiological impact of vertigo it is not inherent to the form of the vertical city. However, the increasing complexity of the multi-level city contains within it a growing potential for disorienting and alienating places. The impact of the cities in these novels on their inhabitants acts as a call to designers to attend to the affective emotional impact of the cities we design. By continually confronting their occupants with incomprehensible complexity and overwhelming scale, these novels powerfully demonstrate the need for our cities provide us with moments of respite or clarity where we can feel secure and grounded. They demonstrate the need for the designers to consciously create spaces that are legible and welcoming, that can become familiar and comforting, that can become home. 


\section{Acknowledgements}

Many thanks to Kye Askins for editorial advice; to Davide Deriu for both inspiring this research into vertigo in the city and for editorial advice; to Nathaniel Coleman, Stephen Graham and Andrew Harris for their critical research and support in approaching the fields of utopia and vertical urbanism; to David Roberts for ongoing insights and advice; and to the anonymous referees.

\section{Bibliography}

Abbott, C., 2007. Cyberpunk Cities Science Fiction Meets Urban Theory. J. Plan. Educ. Res. 27, 122131.

Abrash, M., 2002. Robert Silverberg's “The World Inside,” in: Rabkin, E.S., Greenberg, M.H., Olander, J.D. (Eds.), No Place Else: Explorations in Utopian and Dystopian Fiction. Southern Illinois University Press, Carbondale, pp. 225-243.

Ally Ireson, 2000. Introduction, in: Ireson, A., Barley, N. (Eds.), City Levels. Birkhauser.

Anderson, B., 2009. Affective Atmospheres. Emot. Space Soc. 2, 77-81.

Ansaloni, F., Tedeschi, M., 2016. Understanding Space Ethically Through Affect and Emotion: From Uneasiness to Fear and Rage in the City. Emot. Space Soc. 21, 15-22.

Ballard, J.G., 2006. High-Rise. Harper Perennial, London; New York.

Ballard, J.G., 1962. Which Way to Inner Space?, in: Carnell, J. (Ed.), New Worlds Science Fiction. Nova Publications Ltd, London.

Barlow, A., 2005. Reel Toads and Imaginary Cities: Philip K. Dick, Blade Runner and the Contemporary Science Fiction Movie, in: Brooker, W. (Ed.), The Blade Runner Experience: The Legacy of a Science Fiction Classic. Wallflower Press, pp. 43-58.

Baum, H., 2015. Planning with Half a Mind: Why Planners Resist Emotion. Plan. Theory Pract. 16, $498-516$.

Bloom, C., 1996. Cult Fiction: Popular Reading and Pulp Theory. St. Martin's Press.

Bould, M., 2016. The City in Fiction and Film, week 16: JG Ballard's High-Rise, chapters 1-9 [WWW Document]. URL https://markbould.com/2016/02/15/the-city-in-fiction-and-film-week-16-jgballards-high-rise-chapters-1-9/ (accessed 4.1.16).

Brandt, T., 2003. Vertigo: Its Multisensory Syndromes. Springer Science \& Business Media.

Brandt, T., Arnold, F., Bles, W., Kapteyn, T.S., 1980. The Mechanism of Physiological Height Vertigo: I. Theoretical Approach and Psychophysics. Acta Otolaryngol. (Stockh.) 89, $513-$ 523.

Broderick, D., 2003. New Wave and Backwash: 1960-1980, in: James, E., Mendlesohn, F. (Eds.), The Cambridge Companion to Science Fiction. Cambridge University Press, Cambridge, pp. 4863.

Brown, G., Pickerill, J., 2009. Space for Emotion in the Spaces of Activism. Emot. Space Soc., Activism and Emotional Sustainability 2, 24-35.

Chen, L.-W., Shih, C.-M., 2009. The Public Nature of High-Rise Buildings in Taiwan. Environ. Plan. Soc. Space 27, 317-330.

Collie, N., 2011. Cities of the Imagination: Science Fiction, Urban Space, and Community Engagement in Urban Planning. Futures 43, 424-431.

Davidson, J., 2003. Phobic Geographies: The Phenomenology and Spatiality of Identity. Ashgate, Aldershot, England; Burlington, USA.

Davidson, J., Bondi, L., Smith, M., 2005. Emotional Geographies. Ashgate.

Davis, M., 1992. Beyond Blade Runner: Urban Control, the Ecology of Fear. Open Media.

Dunleavy, P., 1981. The Politics of Mass Housing in Britain 1945-1975: a Study of Corporate Power and Professional Influence. Oxford University Press.

Elden, S., 2013. Secure the Volume: Vertical Geopolitics and the Depth of Power. Polit. Geogr. 34, $35-51$.

Fisher, M., 2014. Things To Come. Frieze.

Forty, A., 1995. Being or Nothingness: Private Experience and Public Architecture in Post-War Britain. Archit. Hist. 38, 25-35. 
Frampton, A., Wong, C., Solomon, J., 2012. Cities Without Ground: A Hong Kong Guidebook. Frith, E., 2009. "Is it burning yet?": The Buildings Behind J G Ballard's Writing [WWW Document]. Archit. J. URL http://www.architectsjournal.co.uk/is-it-burning-yet-the-buildings-behind-j-gballards-writing/5200708.fullarticle (accessed 4.1.16).

Gallese, V., 2003. The Roots of Empathy: The Shared Manifold Hypothesis and the Neural Basis of Intersubjectivity. Psychopathology 36, 171-180.

Gạsiorek, A., 2005. J.G. Ballard, Contemporary British novelists. Manchester University Press; Palgrave, Manchester; New York.

Gifford, R., 2007. The Consequences of Living in High-Rise Buildings. ResearchGate 50, 2-17.

Glendinning, M., Muthesius, S., 1994. Tower Block: Modern Public Housing in England, Scotland, Wales and Northern Ireland. Yale University Press, New Haven.

Gold, J.R., 2001. Under Darkened Skies: The City in Science-fiction Film. Geography 86, 337-345.

Graham, S., 2016a. Vertical: Looking at the City from Above and Below. Verso, London.

Graham, S., 2016b. Vertical Noir: Histories of the Future in Urban Science Fiction. City 20, 382-399.

Greenland, C., 2013. Entropy Exhibition: Michael Moorcock and the British "New Wave" in Science Fiction. Routledge.

Guerraz, M., Yardley, L., Bertholon, P., Pollak, L., Rudge, P., Gresty, M.A., Bronstein, A.M., 2001. Visual Vertigo: Symptom Assessment, Spatial Orientation and Postural Control. Brain J. Neurol. 124, 1646-1656.

Harris, A., 2015. Vertical Urbanisms: Opening up Geographies of the Three-Dimensional City. Prog. Hum. Geogr. 39, 601-620.

Hewitt, L., Graham, S., 2015. Vertical Cities: Representations of Urban Verticality in 20th-century Science Fiction Literature. Urban Stud. 52, 923-937.

Hewitt, L., Graham, S., 2013. Getting off the Ground: On the Politics of Urban Verticality. Prog. Hum. Geogr. 37, 72-92.

Hicks, J., 2014. Residential Differentiation in the Vertical Cities of J. G. Ballard and Robert Silverberg, in: Fraser, B. (Ed.), Marxism and Urban Culture. pp. 137-156.

Hillier, B., 1973. In Defense of Space. RIBA J. R. Inst. Br. Archit. J. 539-544.

Ingold, T., 2000. The Perception of the Environment. Routledge, London; New York.

Ireson, A., Barley, N., 2000. City levels. Birkhauser.

Iser, W., 1978. The Act of Reading: A Theory of Aesthetic Response. Johns Hopkins University Press.

Jacobs, J.M., Cairns, S., 2008. The Modern Touch: Interior Design and Modernisation in PostIndependence Singapore. Environ. Plan. A 40, 572-595.

Jameson, F., 2005. Archaeologies of the Future: The Desire called Utopia and Other Science Fictions. Verso, New York.

Jencks, C., 1977. The Language of Post-Modern Architecture. Rizzoli.

Johnson, J.L., 2011. Non-Representational Theory: Space, Politics, Affect. Emot. Space Soc., Emotional Geographies of Education 4, 195-196.

Keen, S., 2007. Empathy and the Novel. Oxford University Press, USA.

Kitchin, R., Kneale, J., 2002. Lost in Space, in: Lost in Space: Geographies of Science Fiction. pp. 116.

Le Guin, U., 1997. Introduction, in: Attebery, B., Guin, U.K.L. (Eds.), The Norton Book of Science Fiction. W. W. Norton \& Company, New York.

LeBlanc, J., 2011. The Acrophobe and the Funambulist: Existential and Cinematic Perspectives on the Phenomenology of Extreme Vertical Space. Emot. Space Soc. 4, 1-7.

Lees, L., Imrie, R., Raco, M., 2009. Regenerating London: Governance, Sustainability and Community in a Global City. Routledge.

Lewis, D., Rodgers, D., Woolcock, M., 2008. The Fiction of Development: Literary Representation as a Source of Authoritative Knowledge. J. Dev. Stud. 44, 198-216.

New London Architecture, 2016. London Tall Buildings Survey.

McGann, M., Torrance, S., 2005. Doing it and Meaning it: And the Relationship Between the Two, in: Ellis, R.D., Newton, N. (Eds.), Consciousness \& Emotion. John Benjamins Publishing Company, Amsterdam, pp. 181-195.

McGaw, J., Vance, A., 2008. Who has the Street-Smarts? The Role of Emotion in Co-Creating the City. Emot. Space Soc. 1, 65-69.

McNeill, D., 2005. Skyscraper Geography. Prog. Hum. Geogr. 29, 41-55.

Merril, R., 1967. Books (F\&SF, November 1967), in: Ferman, E.L. (Ed.), The Magazine of Fantasy and Science Fiction, November 1967. Mercury Press.

Pinder, D., 2005. Visions of the City: Utopianism, Power and Politics in Twentieth-Century Urbanism. Edinburgh University Press, Edinburgh. 
Roberts, A., 2005. The History of Science Fiction. Palgrave Macmillan, Basingstoke England; New York.

Sandberg, L., Rönnblom, M., 2016. Planning the New City: Emotional Reaction and Positions. Emot. Space Soc. 21, 50-57.

Shelton, B., Karakiewicz, J., Kvan, T., 2014. The Making of Hong Kong: From Vertical to Volumetric. Silverberg, R., 2011. The World Inside. Orion.

Sobchack, V., 2014. Cities on the Edge of Time: The Urban Science Fiction Film, in: Redmond, S. (Ed.), Liquid Metal: The Science Fiction Film Reader. Columbia University Press.

Sobchack, V., 1988. Cities on the Edge of Time: The Urban Science Fiction Film. East-West Film J. 3, 4-19.

Sontag, S., 1964. The Imagination of Disaster. Commentary 40.4.

Spencer, K.L., 1983. "The Red Sun Is High, the Blue Low": Towards a Stylistic Description of Science Fiction. Sci. Fict. Stud. 35-49.

Spicker, P., 1987. Poverty and Depressed Estates: A Critique of Utopia on Trial.

Steyerl, H., 2011. In Free Fall: A Thought Experiment on Vertical Perspective. E-Flux.

Suvin, D., 1979. Metamorphoses of Science Fiction: On the Poetics and History of a Literary Genre. Yale University Press.

Thrift, N., 2004. Intensities of Feeling: Towards a Spatial Politics of Affect. Geogr. Ann. Ser. B Hum. Geogr. 86, 57-78.

Walk, R.D., Gibson, E.J., Tighe, T.J., 1957. Behavior of Light- and Dark-Reared Rats on a Visual Cliff. Science 126, 80-81.

Watt, P., 2009. Housing Stock Transfers, Regeneration and State-Led Gentrification in London. Urban Policy Res. 27, 229-242.

White, J., 2009. London in the Twentieth Century: A City and Its People. Random House.

Whitney, S.L., Jacob, R.G., Sparto, P.J., Olshansky, E.F., Detweiler-Shostak, G., Brown, E.L., Furman, J.M., 2005. Acrophobia and Pathological Height Vertigo: Indications for Vestibular Physical Therapy? Phys. Ther. 85, 443-458.

Yuen, B., Yeh, A., Appold, S.J., Earl, G., Ting, J., Kwee, L.K., 2006. High-rise Living in Singapore Public Housing. Urban Stud. 43, 583-600. 